(Paper No. 2401.)

\title{
"The New Bridge of the London, Chatham and Dover Railway Company over the Thames at Blackfriars."
}

By George Edward Wilson Cruttweld, M. Inst. C.E.

\section{General Description.}

THE new St. Paul's Station in Queen Victoria Street was designed to provide additional accommodation, long needed, on the City side of the river, for the increasing traffic on the London, Chatham and Dover Railway.

Within the station are three terminal lines of way, and on the west side, adjoining the previously existing lines of the same railway, are two through lines, which form a junction with the old lines a little to the south of Ludgate Hill Station. The new lines are carried across the river by the new Blackfriars Bridge, Plate 5, Figs. 1 and 2, which forms the subject of this Paper.

The bridge is designed to carry, in all, seven lines of railway, and has a clear width of 81 feet between the parapets; but this width is increased to 123 feet at the northernmost span, where it was necessary to provide space for the platforms as well as for the lines of way.

In consequence of the great width, and the numerous cross-over roads upon the bridge, it was impossible to enploy a construction like that of the older bridge, consisting of main girders rising above the rail-level, and therefore a system consisting of arched ribs beneath the rails was adopted.

The bridge has five spans; the shore span on the Surrey side being 183 feet; the centre span, and the Middlesex shore span 185 feet each, Plate 5, Fig. 4; and the second and fourth spans 175 feet each; the lengths of the three middle spans correspond with those of the old bridge alongside.

\section{The Abutrents.}

The cofferdams enclosing the abutments were each composed of a single row of sheet-piles of sawn pitch-pine, driven to an average depth of 25 feet below the foreshore, or about 7 feet below the foundations of the abutments. The cofferdams were set forward 
some 27 feet in advance of the foundations, in order to utilize them for the construction of wharves.

On the outside of each cofferdam a trench was dug $2 \frac{1}{2}$ feet wide by 3 feet deep, and filled with clay puddle. The piles being of sawn timber, caulking was unnecessary, except in a few places where leaks appeared on the occasion of the closing of the dam. These leaks were speedily stopped, and the excavations for the abutments were kept dry by means of a 10 -inch pump worked by a 6 HP. engine.

The excavation for the abutment on the Middlesex side of the river was carried down, throughout its whole area, to a depth of 15 feet below Trinity high-water; and below this the excavation was carried 10 feet deeper in bays about 12 feet in width by $37 \frac{1}{2}$ feet long, the latter dimension corresponding with the width of the foundations. Each bay was filled with concrete before the excavation of the adjoining bay was commenced. The bed of the foundations, at a level of 25 feet below Trinity high-water, is about 1 foot beneath the surface of the ballast overlying the London clay. The surface of the clay is about 15 feet beneath the foundations of the abutment.

The abutments consist principally of Portland cement concrete, in the proportions of 8 parts of concrete to 1 part of cement for the lower portion, and of 6 to 1 for the upper; but the springers of Bramley Fall stone, against which the arched ribs abut, are backed up with brickwork in cement, the courses of the brickwork being set at an inclination square to the line of thrust of the arched ribs.

\section{The Plers (Plate 5, Figs. 3 and 5).}

The foundations of Piers 1, 2, and 3 (counting from the Surrey side), were each sunk within three rectangular caissons, spaced about 6 feet apart; whilst, for the long pier on the Middlesex side four caissons were required. Immediately above low-water level arches were turned between the separate portions of the piers built within the adjoining caissons; above the archways the piers are continuous.

The pier-foundations are all carried down to a depth of 46 feet below Trinity high-water, where they rest in the London clay; the depth below the river-bed varying from $16 \frac{1}{2}$ to $23 \frac{1}{2}$ feet.

\section{The Caissons (Plate 5, Figs. 7, 8, and 9).}

The caissons are rectangular, varying in dimensions from 30 feet by 32 feet to 30 feet by 26 feet. They consist of a 
single skin of wrought-iron plate $\frac{1}{2}$-inch thick, for the bottom 7 feet, and diminishing to The lower portion, or permanent caisson, is, in each case, 21 feet in height; and above this a temporary caisson was carried up to a further height of 28 feet, this portion being bolted to the permanent caisson, and removed after the building of the pier inside was sufficiently advanced.

The caissons were stiffened vertically at the corners by angleiron, and on the sides by tee-irons spaced at intervals of about 7 feet, and were further strengthened by temporary horizontal stiffeners placed about 4 feet apart. For the latter purpose wrought-iron girders and diagonal struts were at first employed; but, owing to the difficulty of removing them under the great pressure, it was. afterwards found better to employ timbering.

The cutting-edge of the caisson was of rolled-iron, stiffened by means of triangular gussets butting against the underside of the lowermost horizontal girder, and other gussets were placed above the girder to prevent its yielding upwards. The pressure on the lower gussets proving somewhat greater than on those above, it was found in some instances that the girder bent slightly upwards and allowed the cutting-edge to be forced inwards to some extent. This necessarily impeded the descent of the caisson, and after the experience gained in sinking the first caisson, the gussets of all the remaining caissons were strengthened. The bottom girder and gussets were designed to be left in permanently.

The upper horizontal frames were stiffened vertically by temporary timber puncheons fitted between them.

At the top of the permanent caisson thickening strips were riveted to the skin plates to give them additional width, and on these rested the temporary caisson.

The bottom of the temporary caisson consisted of inverted channel-irons, containing flat strips of vulcanized india-rubber, and the joint was tightened up by means of bolts spaced about 2 feet apart round the edges of the caisson.

The vertical and horizontal stiffeners of the temporary caissons were generally similar to those of the permanent caissons although of a lighter description.

\section{Erectixg and Lowering the Caissons.}

For erecting and sinking the caissons a staging was constructed around the site of each pier.

After the permanent caissons had been riveted together and the temporary girders fitted inside them, two pairs of trussed beams 
were placed above each caisson, with their ends supported on the staging at the sides. Between each pair of beams, near the four corners of the caisson, was placed a suspension or lowering rod, $2 \frac{1}{4}$ inches in diameter, which passed down inside the caisson, and was secured by a cotter under the bottom horizontal girder. The latter was stiffened by extra gussets at this point. The rods were in lengths, coupled together by pins. The top length of each rod was $2 \frac{1}{2}$ inches in diameter, and on it a square thread was cut for a length of 6 feet from the top.

When the rods had been fitted in position, the caisson was lifted clear of the low-level platform on which it was built by means of the screwed rods, and the platform being removed from beneath, the nuts were turned in the opposite direction, and the caisson was lowered steadily down. To ensure uniformity in the descent of the four corners, spanners were provided for each of the four screws, and ropes attached to the spanners were passed round snatch-blocks, and connected to a movable crane which travelled along the stage at the side of the caisson, and thus turned each of the spanners by the same amount. The crane then returned to its starting point, the spanners and ropes were re-adjusted, and the process was repeated until the lowering had brought the ends of the screwed rods nearly down to the nuts.

It was then necessary to couple on another length to the lowering rods. This was performed by taking the weight of the suspended caisson upon four large wrought-iron hooks passing under the cutting-edge and connected to rods passing up outside the caisson, between the trussed beams. These rods were coupled in lengths and furnished with screws at their upper ends similarly to the rods inside the caisson.

As soon as the caisson reached the bed of the river (which had been previously dredged so as so give a level bearing for the cuttingedge), the outer rods were detached, and the hooks were removed from beneath the cutting edge by divers.

The inner rods were lengthened as the sinking proceeded, and were retained until the caisson was lowered to its full depth; as they were found indispensable for controlling the caisson during its descent. Apart from the duty of keeping the caisson level, the rods, by allowing one side or one corner to take the lead, afforded the means of regulating the lateral position of the caisson with great nicety.

The temporary caisson was added during the process of sinking, as soon as sufficient depth was gained to admit of the sections being built beneath the suspension beams. 


\section{Excavating Inside the Caissons.}

The silt, ballast, and the upper portions of the clay inside the caissons, were excavated by means of Priestman's grab machinery, the grabs being worked by movable jib-cranes. The quantity excavated at each "grab" varied from $\frac{1}{4}$ to $\frac{3}{4}$ cubic yard, and when in full work about fifteen grabs were made per hour.

On account of the girders and timbering inside the caissons, the grabs could not approach their sides and corners, and it was necessary to employ divers to shovel the material towards the middle.

The caissons were weighted with kentledge to facilitate the sinking, and under this load the cutting-edge penetrated at first below the excavation; but as the sinking progressed and the friction increased, it became necessary to excavate down to the cutting-edge; and in some cases it was with difficulty that the caissons were forced down to their full depth. This was especially so in the case of the caissons of pier No. 4, which had to be sunk through thick layers of septaria embedded in the London clay.

To aid the descent of the caissons of this pier, hydraulic presses were applied, the purchase being obtained against the undersides of inverted trussed beams laid across the caissons, and secured to the piles of the staging surrounding the pier. When the presses at each corner of one of these caissons were exerting a pressure of 30 tons each, or 120 tons together, the total load on the caisson amounted to 390 tons, the hydraulic pressure being aided by the weight of the caisson, including timbering, \&c., which was estimated at 143 tons, and also by the weight of the kentledge, amounting to 127 tons.

The least pressure exerted was in the case of one of the caissons of pier No. 2, where the caisson, including timbering, \&c., weighed 108 tons, and the kentledge 117 tons, or a total of 225 tons.

As soon as the caissons had been sunk well into the clay they were pumped free of water, and the digging was continued. At first it was found necessary to carry on the excavation only at low-water, and to admit water into the caisson as the tide rose; but as the caisson penetrated to a safer depth into the clay, the time of working was extended, until, on reaching the finished bottom of the foundations, the tide was kept out altogether, and the concrete work inside was then commenced.

In the case, however, of three of the caissons of pier No. 4, and the easternmost caisson of pier No. 3 , it was unsafe to allow the full 
pressure of water at high-tide on account of the leakage which then took place through the clay; and the sluices had therefore to be opened at each tide until the concrete had been brought up 3 feet above the bottom, and the leaks had been overcome.

The average depth through which the caissons were lowered, whilst the grabbing and divers' work was in progress, amounted to about 4 inches daily; but when the pumping-out and excavating was commenced, the average daily descent was increased to about 15 inches-the maximum in any single day having been 2 feet 9 inches.

The descent of the caissons was greatly impeded by layers of septaria which were met with at intervals in the clay. The average thickness of these layers was about 6 inches, and the separate boulders of which the layers consisted measured from 2 to 4 feet across.

At pier No. 4, where the depth of the silt and ballast overlying the clay amounted to $\mathbf{1 4}$ or 15 feet, a water-jet was used for displacing the material round the edges of the caissons-thus obviating much of the divers' labour in digging and shovelling. The jet was driven by a steam force-pump, through a 2-inch flexible tube, and through a nozzle $\frac{3}{4}$-inch in diameter, which was directed by the diver. The daily rate of progress by this method averaged about 6 inches, as against 4 inches in the case of the ordinary digging by divers.

The caissons were in every case cleared of water by Woodford's centrifugal pumps, and their working proved satisfactory.

\section{Construction of the Piers.}

The foundations of the piers inside the caissons consisted, for a lieight of 17 feet above the bottom, of solid cement concrete in the proportion of 6 parts of concrete to 1 part of cement, in layers corresponding in thickness to the height between the frames of the caissons.

The concrete having been raised to within about 3 feet of the underside of any one of the temporary horizontal frames, blocks of stone were bedded in it about 4 feet away from the sides of the caisson, and at intervals of about 6 feet apart; and between these and the angle-iron shelf which supported the frame, raking struts of timber were jammed tight by means of folding wedges. These struts prevented the sides of the caisson from being forced inwards on the withdrawal of the temporary frame, which was effected as soon as the concrete had been brought up to 
the underside of the frame. The raking struts were left in permanently; being of small scantling (about 5 inches by 5 inches) it was considered that they did not impair the efficiency of the concrete foundations to any appreciable extent.

It was at first attempted to withdraw the frames without inserting these struts, merely trusting to the concrete to resist the pressure from the outside; but it was found, even after the concrete had been left to set for four days, that its upper surface was dislodged round the edges, thus allowing the sides of the caisson to be forced inwards to some extent. A great saving of time was therefore effected by inserting the struts, as the frame could be drawn at once, instead of waiting a week or more for the concrete to become sufficiently hard to resist the pressure.

In this manner the concrete was brought up frame by frame, until, at a level of 4 feet below the top of the permanent caisson, the brickwork was commenced. This was butted tight against the skin of the caisson up to the underside of the top frame of the permanent caisson, and on the withdrawal of the frame its place was made good with brickwork.

At the level of the top of the permanent caisson, or 25 feet below Trinity high-water, a set-off of the brickwork occurs, and at this level the granite facing begins. The method of building was as follows :-A course of masonry having been laid beneath a frame, and the backing put in, and the whole having become sufficiently set, the skin of the temporary caisson was strutted against the masonry, thus enabling the diagonal struts of the frame next above to be removed ready for the carrying up of the next course of masonry past the frame.

In this manner five or six courses of masonry, extending to a height of 6 or 8 feet above low-water, were set inside the temporary caissons; but at the ends of the adjoining caissons, where the connecting arches had to be turned, only three courses of masonry, rising just above low-water, were set.

The work having been brought up thus far, the temporary caissons were removed, and the connecting arches, together with the remainder of the work below high-water, were put in by tidework.

On account of the bed-plates of the ribs being set back inside the face lines of the pier, none of the work between or above the bed-plates could be built until after the ribs had been finally fixed in position. Before entering upon the manner in which this operation was carried out, a brief description of the ribs themselves and of the other parts of the superstructure will be given. 


\section{The Iron Superstructure (Plate 5, Figs. 4 and 6).}

The arched ribs are of segmental form. The width of span varies as stated at the beginning of this Paper, but the rise of all the spans is the same, viz., 18 feet 6 inches, which is equivalent to from one-ninth to one-tenth of the spans. The springing-level is 7 feet 6 inches above Trinity high-water, and the headway at the centre of each span is 26 feet at high-tide.

The ribs, Plate 5, Fig. 10, are of a uniform depth of 4 feet 6 inches, and the web-plate is everywhere 4 feet 2 inches deep. In order to obtain this similarity of depth with a varying strength of rib in due proportion to the strains, the areas of the flanges at the different sections in their length are modified, not by altering the number of the flange-plates, but by altering the widths of some of them. At the quarter spans, where the greatest strain is caused by unequal loading of the bridge, the flanges are each made up of four $\frac{3}{8}$-inch plates 18 inches wide; but at the ends and centres of the spans, where less strength is requisite, there are only two plates of the above width, and the remaining two are 9 inches wide, the area of the flange-plates in the latter case being thus only threefourths of the area in the former case.

At the sides of each flange iron angle-bars are riveted, which add both to the appearance and to the strength of the ribs.

At the back of each heel-plate is a wrought-iron forging turned at the back so as to bear upon the half-circumference of a cylindrical pin of wrought-iron 8 inches in diameter, which rests in a semi-cylindrical socket, forming the front portion of the bedplate. The heel-forging, cylindrical pin, and socket of the bedplate are each 1 foot 7 inches in width, so that the bearing area upon the pin normal to the line of thrust is 152 square inches. As the maximum thrust that can occur along a single rib is 270 tons, the maximum pressure per square inch of bearing is thus about $1 \frac{3}{4}$ ton.

The thrust is distributed by stiffened wrought-iron plates upon a rectangular back-plate 4 feet in height by 4 feet 6 inches in width. In order to give the plate a uniform bearing over the springers, it was packed off about $\frac{1}{8}$ inch clear of the latter, and fine cement grout was poured in behind. With the same thrust as given above, the maximum pressure at the back of the bed-plate amounts to 15 tons per square foot.

The ribs being free to pivot about their cylindrical bearings at either end, the forces acting along the flanges and web could be 
accurately defined, and a more economical distribution of metal ensured than in the case of a rib taking its bearings over the greater portions of its end surfaces.

The web-plate is of a uniform thickness of $\frac{1}{2}$ inch; but at the ends, where the flanges converge towards the centres of the heelplates, an additional web-plate is riveted on at each side, and over these a tie-plate connects the points of divergence of the flangeplates.

The arched ribs are sufficiently stiff in themselves for the loads they have to bear, and there are no braced spandrels between them and the upper longitudinal girders carrying the flooring of the bridge.

The transverse intercostal bracings between the ribs occur at about every 10 feet throughout the length of the ribs. The top member of the bracing consists of a pair of continuous angle-bars, riveted to the top flanges of the ribs; and the bottom member is also a pair of angle-bars rendered continuous by being riveted to bars passing through holes cut in the web-plates of the ribs near their lower edges. The diagonals connecting the top and bottom members meet at the centre of the latter between each pair of ribs, as shown in the transverse section. This system, whilst it prevents lateral movement of the ribs, aids also in distributing the vertical loads from one rib to another.

The posts, carrying the upper girders of the superstructure, are riveted to the top flanges of the arched ribs and consist of three channel-irons riveted together.

There is no longitudinal bracing between the posts on the inner ribs, but transversely the bridge is braced in the line of the posts by a double set of flat diagonal bars.

The cross-girders rest upon, and are riveted to, the tops of the posts, and are continuous from side to side of the bridge.

The longitudinal girders are fitted between the cross-girders, and are in line with the arched ribs below. Two intermediate crossgirders between the longitudinals further subdivide the spaces between the main cross girders. Flat floor-plates $\frac{11}{3} \frac{1}{2}$ inch in thickness are laid over the whole surface (except across the tops of the piers), and are riveted to the angle-bars forming the top flanges of the girders.

The longitudinals are of the same depth as the cross-girders, and are connected to them by vertical angle-bars at each end of the web-plate; and strips, connecting the top flanges of the longitudinals, are laid across the cross-girders above the floor-plates; the longitudinals may therefore be considered continuous. The floor-plates, riveted to their top flanges and to those of the

[THE INST. C.E. VOL. CI.] 
cross girders, form an additional connection between the whole of the upper girders, both in a longitudinal and in a transverse direction.

The longitudinal girders and floor of the bridge were made continuous, to counteract the effect of unequal loads of the various spans on the piers and foundations.

The continuity is unbroken throughout the length of the bridge, for, between the box cross girders on each side of the piers, girders are placed in line with the rest of the longitudinals, but of larger sectional area than the ordinary longitudinals, so as to compensate for the absence of the additional strength given to the latter by the floor-plates. The connections of these pier girders to the box cross girders are also of increased strength.

Owing to the absence of bracings in a longitudinal direction between the posts, any tendency of the latter to move longitudinally under the influence of a travelling load is checked by the continuity of the longitudinal girders, upon which a pull or a push is thrown by the action of the travelling load.

In the design, the stress that might be thrown on any of the longitudinal girders by a train getting off the line was especially considered. To guard against this contingency also, the longitudinal girders, upon which the lattice-work parapets are fixed, were made of considerable strength.

The ultimate pull of the longitudinals is taken at each abutment by ties securely anchored, and of strength sufficient to control the contraction due to change of temperature. The riveting up of the longitudinals to the cross-girders was done at a temperature of $50^{\circ}$ Fahrenheit.

Besides the ties to control the contraction, the abutments are made of sufficient stability to withstand the thrust due to any probable rise of temperature above $50^{\circ}$. On the Middlesex side the thrust is taken by the abutment, and distributed thence on to the viaduct, which extends from the abutment up to the new station building. The pull is taken by tie-bars placed across the top of the abutment, and connecting the longitudinals of the bridge with the continuous wrought-iron girders which form the superstructure of the viaduct.

On the Surrey side, heavy arched ribs of brickwork were thrown across between the back of the abutment and the two adjoining piers inside the Blackfriars goods depot. The piers were further strengthened by buttresses and cross walls of brickwork. By these means the thrust from the longitudinal girders is communicated through the brick arches and into the piers, where its 
line of direction falls well within the base of the foundations. The pull is taken by tie-bars which pass on both sides of the arched ribs of brickwork, and are firmly keyed into castings bedded against the back of the pier.

With regard to the actual execution of the riveting between the longitudinal and cross-girders, it was only at the joints next the piers and abutments that consideration had to be given to the temperature. All the other joints were riveted as the work progressed, and without reference to the temperature; for the spring of the posts gave sufficient play for expansion and contraction.

When all the joints were connected, except those next each pier and abutment, the lengths for the longitudinals to complete the work were measured when the thermometer stood at $50^{\circ}$ Fahrenheit. The girders were prepared, and one end of each was connected to the cross-girder next each of the piers and abutments. The holes for the rivets connecting their other ends to the adjoining cross-girders were then drilled, at the same temperature of $50^{\circ}$ Fahrenheit, or as nearly as possible thereto-a variation of about $2^{\circ}$ on either side of $50^{\circ}$ being allowed. To give room for expansion during the interval before finally riveting these joints, a space was left between the end of each longitudinal and the cross-girder, and this space was fitted at the correct temperature /with a packing-plate, the plate being removed for the time, and only inserted when all the joints were drilled and ready for riveting.

At the beginning of January 1886, all the joints being prepared, the packing-plates were inserted when the temperature was low (at which time the contraction of the ironwork gave space for their insertion without difficulty), and the riveting had then to be deferred until the temperature had risen sufficiently to enable the rivets to be got in. During the cold weather, when the thermometer stood at about $26^{\circ}$ Fahrenheit, the rivet-holes in the angle-bar lugs, fastened to the cross-girders and connecting them with the longitudinals, did not correspond with the holes in the web-plates of the longitudinals by about $\frac{3}{16}$ inch, thus showing a contraction of twice this amount for each span, and ten times the amount, or nearly 2 inches for the whole bridge, which measures 987 feet between the abutments. As the holes corresponded with one another when they were drilled at a temperature of $50^{\circ}$, this contraction of 2 inches was caused by a fall of temperature of $24^{\circ}$, and this is nearly the calculated amount by which a length of 987 feet of iron should contract. 
At the end of January some warmer weather was experienced, and the rivets connecting the longitudinals to the cross-girders were all got in during a single day. The minimum night temperature was fortunately only $8^{\circ}$ below the maximum during the day, so that little strain was put upon the rivets by the contraction during the night; the next day the floor-plates over the joints were laid down, thus completing the connections and rendering the whole secure.

Since the final riveting was completed, a large variation of temperature has been experienced; on examination of the rivets no damage appears to have occurred to any of them from the tensional strain to which they have been exposed by the contraction of the ironwork; whilst the abutments show no signs of any movement under the thrust thrown upon them by the expansion.

The whole of the ironwork in the bridge was constructed by the Thames Ironworks and Ship Building Company of Blackwall.

The Board of Trade inspection of the bridge was made by General Hutchinson during the last week of April 1886.

The lines of way on each span were loaded, two at a time, with locomotives extending the length of a complete span. The maximum deflection at the crown of the arch when fully loaded was $\frac{3}{4}$ inch. The weight of the locomotives was equivalent to $1 \cdot 5$ ton per lineal foot on each line of way, and the proportion of this carried by each of the arched ribs was 0.7 ton per lineal foot. The dead load carried by each rib, including the weight of the rib itself, averaged 0.5 ton per lineal foot; so that the total load on each rib, when fully loaded, amounted to $1 \cdot 2$ ton per lineal foot.

It may be observed that, before any of the superstructure of the bridge was erected, some experiments were carried out at the works of the Thames Ironworks Company at Blackwall, and the load then placed upon the rib amounted to $1 \cdot 25$ ton per lineal foot. The deflection under this load was 0.9 inch; so that the result of this experimental test and that of the Board of Trade agree well with one another.

The load upon the foundations of the piers amounts to $4 \frac{3}{4}$ tons per square foot with the maximum possible load upon the bridge. There was no settlement under the Board of Trade tests.

The total cost of the bridge, including all temporary works, amounted as nearly as possible to $£ 3$ per superficial foot of the area of the flooring.

The joint Engineers for the works were Mr. William Mills of the London, Chatham and Dover Company, and Messrs. J. Wolfe 
Proceedings.] CRUTTWELL ON BLACKFRIARS NEW RAILWAT BRIDGE. 37

B. rry and H. M. Brunel. The chief direction of the design and exe'ution rested with the two last-named gentlemen. The Author of $t$. s Paper was the Resident Engineer.

Nine sheets of detailed drawings are submitted with the Paper, and from these a selection has been made, and reproduced in Plate 5. 

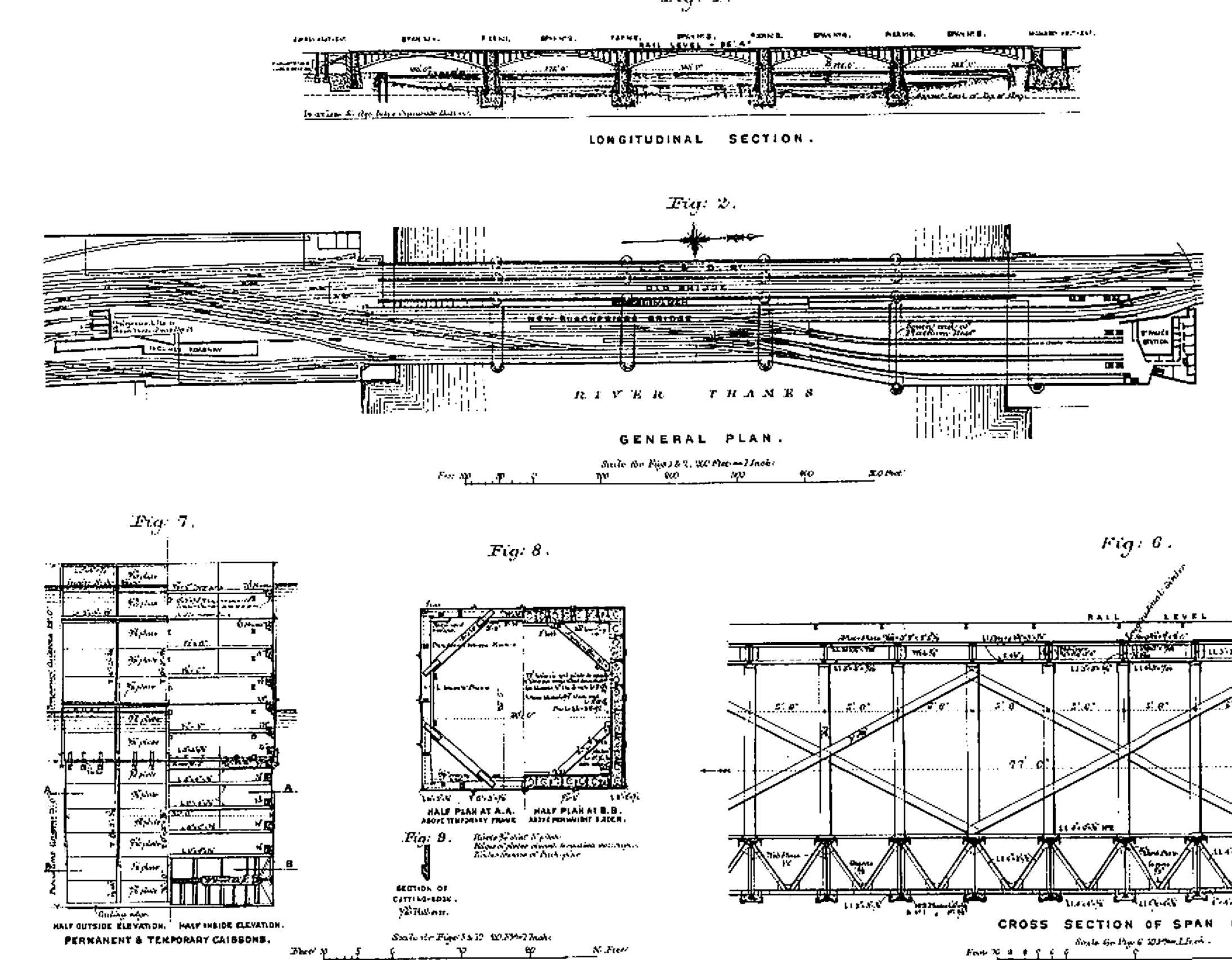
(n)
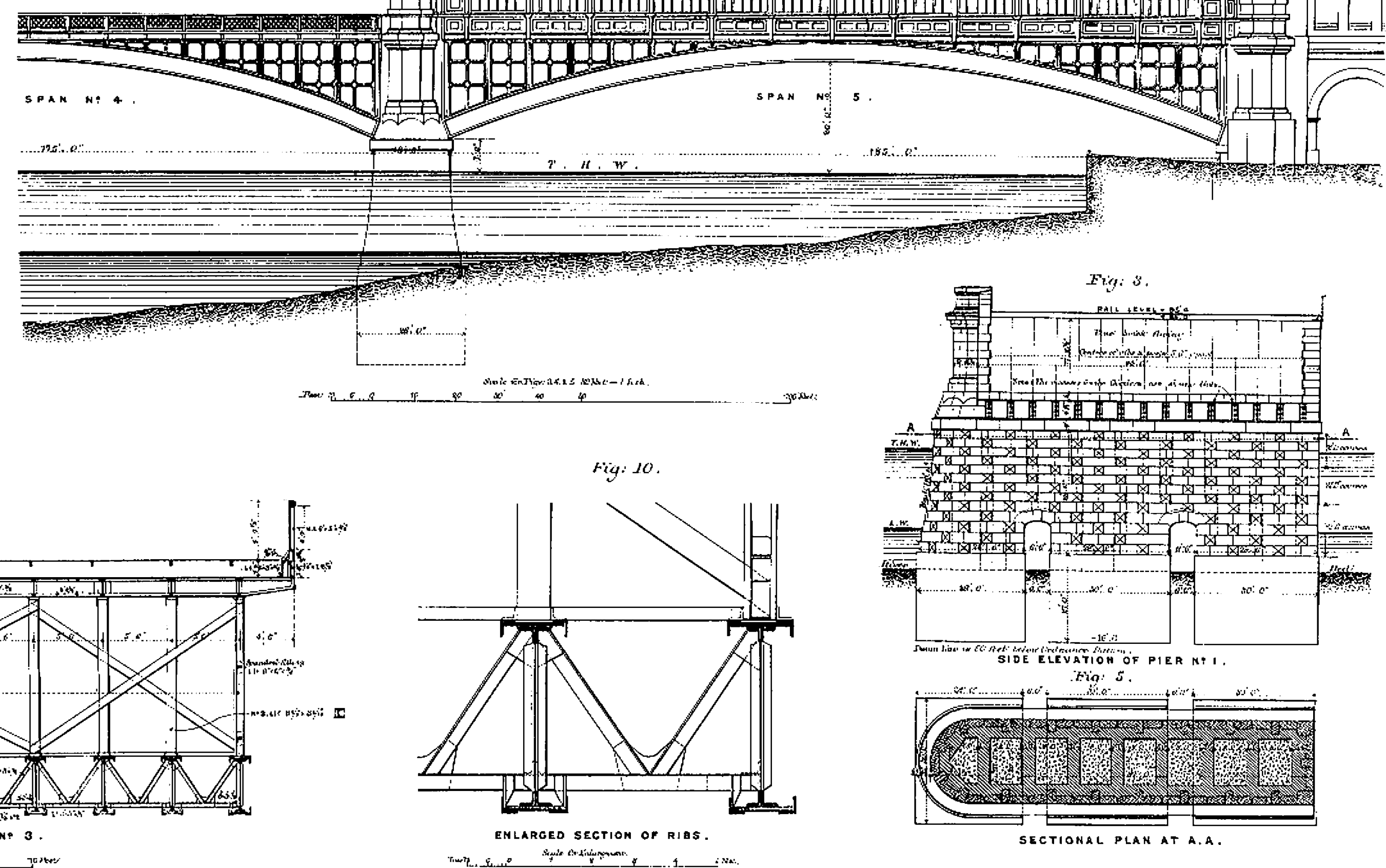

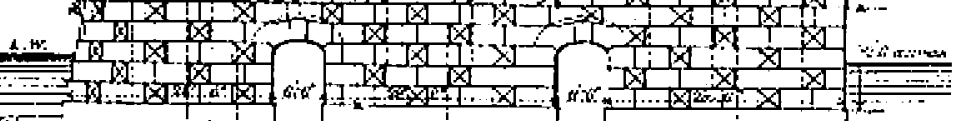

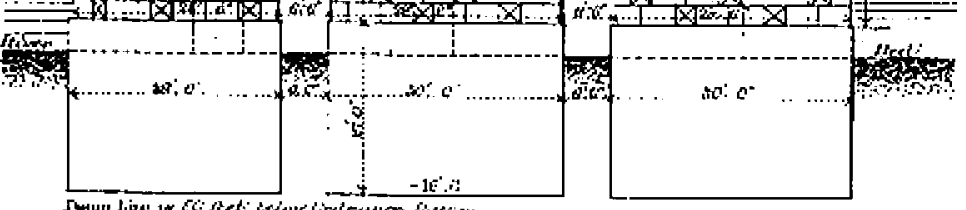
SECTONAL PLAN AT A.A. 